\title{
IDEOLOGY IN MODERN TIMES: THREE IDEOLOGICAL LIES BEHIND UNIVERSAL HUMAN RIGHTS
}

\author{
WOJCIECH ZOMERSKI*
}

\section{INTRODUCTION}

When the Soviet Union collapsed, it was believed that the following century would be time of the end of history, politics, and ideology ${ }^{1}$. As a result, the times of liberal democracies seem to be post-ideological and postpolitical. An opposing view has, however, emerged insomuch that our times are considered more ideological than they have ever been before ${ }^{2}$. The main aim of this paper is to consider whether modern times are post-ideological and post-political or not. The concept of human rights, a crucial foundation of liberal democracies, will serve as a reference. ${ }^{3}$ However, before I am able to analyze the ideological and political dimension(s) of human rights, I will try to reconstruct the notion of ideology and the political as itself.

\section{MARX'-ORWELL'S VS HUXLEY'- ŽIŽEK'S DEPICTION OF IDEOLOGY}

The starting point to Žižek's deliberation on ideology is a reconstruction of Marx's definition of ideology. A well-known phrase from Capital aptly defines this: "they do not know it but they are doing it" ${ }^{\text {"4 }}$. Being

DOI: $10.1515 /$ wrlae-2015-0027

*Master of Law at The University of Wroclaw \& University of Salzburg \& Loyola University, New orleans; President of The Legal Philosophy Society of the Faculty of Law, Administration and Economics, University of Wrocław 2013/2014, trainee at the Helsinki Foundation for Human Rights (July 2014), trainee at the Embassy of the Republic of Poland in London (August - September 2014), w.zomerski@gmail.com.

${ }^{1}$ Cf Francois Fukuyama, The End of History and the Last Man (Free Press 1992).

2 Slavoj Žižek, Wzniosty obiekt ideologii (trs Joanna Bator and Paweł Dybel, Wydawnictwo Uniwersytetu Wrocławskiego 2001).

${ }^{3}$ Costas Douzinas, Human Rights and empire: the political philosophy of cosmopolitanism (Taylor \& Francis e-Library 2007) 177.

4 Žižek, Wzniosty obiekt ideologii (n 2) 42. 
under the influence of ideology implies perceiving reality in the wrong way. In other words, being under the influence of ideology is the equivalent to being intentionally manipulated.

Meanwhile, Žižek's main point is that comprehending the ideology of our times requires abandoning Marx's outdated concept of ideology in itself. He proposed a contrary, revised definition of ideology which finds meaning in the phrase coined by German philosopher Peter Sloterdijk: "they know very well what they are doing, but still, they are doing it" ${ }^{5}$. This view is based on the fact that modern society consists of cynical individuals who are aware of the gap between the ideological mask and reality yet still insist upon wearing the mask ${ }^{6}$.

I find the two famous books written by Aldous Huxley ${ }^{7}$ and George Orwell $^{8}$ as useful material to understand the difference between Marx' and Žižek's depiction of ideology. Both writers wrote a compelling description of a futuristic dystopia. Even though both books are nightmare visions of society under the control of a ruling clique, there is no doubts that they show the machinery of ideology in a different way ${ }^{9}$.

The nature of the ideology in Nineteen Eighty-Four finds expression in one of the last of O'Brien's statements, who tells the recently-converted Winston: "You must love Big Brother. It is not enough to obey him, you must love him" "In Orwell's world, ideology never gets satisfied, it always wants more and more. The Party and Big Brother penetrate all daily activities and life's areas. As a result, when something is not controlled by the Party, it is automatically outside of the ideology. As a consequence, the members of the party not only live their lives believing in the Party, but believing they actively participate in their beliefs. Everything they do is in the name of the Party. On one hand, this omnipresence of ideology is power in itself and, on the other, it is its Achilles' heel. As long as Winston believes in the Party, he obeys the ideology. However once belief is lost, then everything the Party says, all the statistics from the telescreen, become invalid ${ }^{11}$.

The ideology in Brave New World is not so transparent. An inattentive reader could be led to believe that there is no ideology in Huxley's world. Citizens of the World State are encouraged to make love to as many people as possible. When somebody is stressed, he or she is recommended to take Soma, which seemingly makes everyone happy. In contrast to Nineteen Eighty-Four, slogans and propaganda do not surface. Ideology, in Huxley's view, is not a way of perceiving reality, it is reality. There is no need to stifle

\footnotetext{
5 ibid 44.

${ }^{6}$ ibid.

${ }^{7}$ Aldous Huxley, Brave New World (first published in 1932 by Chatto \& Windus) $<$ https://archive.org/download/ost-english-

brave new world aldous huxley/Brave New World Aldous Huxley.pdf> accessed 4 July 2014.

${ }^{8}$ George Orwell, Nineteen Eighty-Four (first published in 1949 by Secker and Warburg) $<$ http://www.planetebook.com/ebooks/1984.pdf $>$ accessed 4 August 2014.

9 Emmet Scott, 'Orwell, Huxley and the Emerging Totalitarianism' (May 2013) $<$ http://www.newenglishreview.org/custpage.cfm/frm/138161/sec $\mathrm{id} / 138161>$ accessed 4 July 2014

${ }^{10}$ Orwell (n 8) 355

11 Slavoj Žižek, 'Ideology, the Party' (1 December 2011) $<$ https://blogs.commons.georgetown.edu/engl-246-fall2011/2011/12/01/zizek-ideology-theparty/> accessed 4 August 2014
} 
some working class riots as, due to genetic modifications, epsilons are incapable of rioting. There is no need to rewrite history; it is easier and more effective to get rid of it. Of course, analyzing the whole image of ideology in Brave New World shows that there are some common points with Orwell's reality. Similarly, there is no place for religion, art or individualism but, as I have been trying to show, there is a crucial difference in achieving this aim. In the World State, people are not forced to obey the ideology, they are just incapable of not following it. As a result of being raised in the World State, people treat their reality as something natural and neutral. In Orwell's Oceania, ideology is based on lies, propaganda and false perception of reality - in the World State the reality is a lie.

Accordingly, whenever Žižek agrees that we live in post-ideological times, he does not mean that today there is no ideology at all, but that modern ideology is no longer based on simple unconsciousness. In other words, he agrees that there is no more ideology in the old sense of Marx and Orwell. What was shown by Huxley finds meaning in Žižek's phrase: “The mask is not simply hiding the real state of things; the ideological distortion is written into its very essence" $"$.

\section{Chantal Mouffe's Term of "The Political"}

As shown, the legitimacy of the ideology in Brave New World is stronger than in Nineteen Eighty-Four. To be able to consider the consequences of the intensification of the ideology in Huxley's book, I need to bring in the term the political into my study. The political was a term coined by Carl Schmitt and was later revised and renewed by Belgian political theorist Chantal Mouffe ${ }^{13}$.

Mouffe considers modern reality as post-political given liberal democracy is no longer a counterbalance to real socialism and, as a result, is the only current idea on how to govern a state ${ }^{14}$. In her opinion, since the idea that the biggest value in politics is consensus emerged, democracy has lost its political aspect ${ }^{15}$. Consequently, running a country is no longer a series of political choices in view of the fact that changes are dictated by economic efficiency and technocratic rationalism.

The classic depiction of the political was based on antagonism and the distinction between friends and enemies. Schmitt considered the idea of democracy as a negation to politics as itself. Mouffe tries to deploy Schmitt's output to answer the question as to how to liberal democracy can be rescued from the final loss in the post-political ${ }^{16}$. She suggested replacing antagonism with agonism and, as a consequence, replacing the relation between enemies to adversaries ${ }^{17}$. She does not want to abandon the notion of democracy, on the contrary - she would like to straighten it by leaning democracy on the

\footnotetext{
12 Žižek, Wzniosty obiekt ideologii (n 2) 43.

${ }^{13}$ Chantal Mouffe, Polityczność (tr Joanna Erbel, Wydawnictwo Krytyki Politycznej 2008).

14 ibid 16.

15 ibid 22.

${ }^{16}$ ibid 29 .

17 ibid 36.
} 
idea of pluralism. She understands politics as a space for political camps which compete with each other. While every consensus implies exclusions, resting politics on conflicts between members of society enables everyone to at least identify with a particular political camp. She also noticed that the need of conflict is deep-rooted in human nature and that leaving out agonism always implies the appearance of antagonism ${ }^{18}$.

What is then the main difference between the enemy and adversary apart from the semiotic one? An adversary is the opponent in a political category, while the enemy is judged by the position of morality. An adversary might be beaten in a democratic election and, even then, there would still be a place for him or her in the democratic space. Being considered as an enemy implies that there is no such thing that could not be done to get rid of him or her. Enemies discredit each other as people, while adversaries challenge only each other's views.

Moving to the conclusion of this part, let me explain why the term the political is useful in terms of deliberations on ideology. The main point is that the less political reality is, the bigger a role ideology plays. As shown in the first part of my dissertation, the legitimacy of ideology in Huxley's world is stronger than that of Orwell's. In other words, it is possible to notice some remains of the political in Oceania, whereas Huxley's reality seems to be highly unpoliticized. This thesis could be depicted by analyzing the position of the enemy in these two dystopias.

In Orwell's Oceania, enemies function on two separate levels. There is an enemy in foreign relations apropos Eurasia and Eastasia. There is no doubt that they are enemies in Schmitt's antagonistic depiction; however, when we consider the relationship between O'Brien and Winston, it is not so straightforward to categorize this relation. Undoubtedly, O'Brien does not see a place for Winston in the political dimension of Oceania; however, at the end he discredits his views but not him as a person. At some point, he had even cynically admitted that they are too similar to one another ${ }^{19}$. However, no matter whether it is an agonistic or agonic relationship, the very fact that the Party still engages in the political fight shows that there still is a place for some discussion and that ideology has not yet won.

In Huxley's World State there is no enemy at all. Even Bernard Marx, who does not share all ideological views, is not treated as an enemy. People treat him rather as a harmless freak. Even when threatened of being exiled to Iceland by Mustafa Mond, at the end it materialized that he had a choice of whether he wanted to move or not.

It must be pointed out that the one who proved that it is possible to come out of the ideology is the Savage. However, it must be taken into consideration that:

(i) he wasn't brought up in the World Sate,

(ii) the only possibility of running out of ideology was not possible within the scope of reality and it implied putting himself outside society,

(iii) and, last but not least, that the World State society, or even governors, have not considered the Savage as any kind of enemy.

18 ibid 40.

${ }^{19}$ Orwell (n 8) 326. 
Just as in the case of Bernard Marx, they treated him as some freak or tourist attraction.

Keeping the aforementioned facts in mind, one may argue that Huxley built the least political reality that could be imagined.

\section{The Politics of Universal Human Rights}

Taking the above-reconstructed terms of the ideology (in HuxleyŽižek's meaning rather than Marx-Orwell's) and Mouffe's understanding of the political into account, we are eventually able to analyze the ideological and political dimension of human rights which would lead to the conclusion whether our time may or may not be described as ideological and/or political.

When considering the legal foundations of liberal democratic order, the politics of universal human rights naturally comes to $\operatorname{mind}^{20}$. From the formal-legal point of view, human rights are a subcategory of legal rights, given special status and protection due to the importance of the goods or actions they protect and promote - typically described as dignity, freedom, and equality ${ }^{21}$.

As noticed by Douzinas, the rehabilitation of natural rights under the new guise of human rights dates from the Nuremberg trials of the Nazi war criminals $^{22}$. The significance of those trials was expressed in the sense that customary law of civilized nations could not be overridden by national laws. Since then, human rights have been gradually moving from the theoretical discourse to the political. It soon occurred that human rights, as a part of widely-understood politics, are understood disparately in different parts of the world. Human rights seen from the Western perspective, above all, were and today still remain political rights. The Soviets responded that social and economic rights are superior, which finds expression in the sentence: "the right to a free press is of no interest to a starving and illiterate peasant in an African village, 23 .

As long as two opposite political camps were present in politics, nobody even had an illusion about the universalism of human rights. The situation changed dramatically in 1991 when real socialism as a way of ruling the country was buried along with the Soviet Union. Human rights then moved from being a weapon between Western and Eastern policies to the corner stone of the new world order. Since then, human rights in Western optics have become something universal, natural and neutral.

To understand the ideological character of universal human rights, let's consider the Marxist point about the ideology in law which he defined as: "a gap between the ideological appearance of the universal legal form and the particular interests that effectively sustain it" 24 . Therefore, proving that the concept of universal human rights is ideological requires proof that term universal human rights does not mean what people think it does. Where are

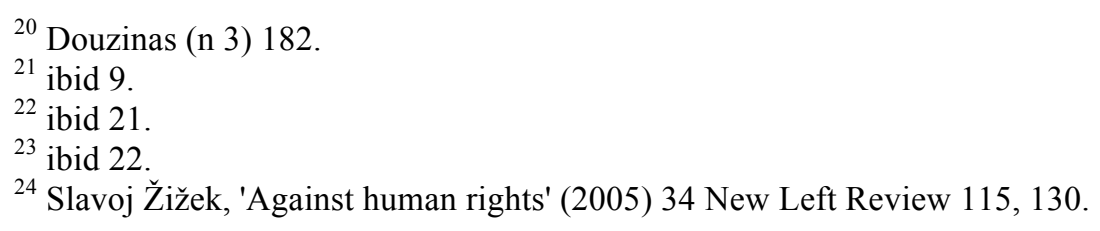


these lies hidden? To give a clue, it could be said that in the term 'universal human rights' there are as many lies as there are words which the term is made of.

Let's start with this banal question: who is the bearer of the human rights? To give a genuine answer, the status of refugees or stateless people ${ }^{25}$ who are not fully entitled must be considered as there is no government to protect them. Although the detention center in Guantanamo Bay has been discussed ad nauseam, it seems that along with 'black sites' governed by the US government in Eastern European countries are adequate examples of proving that human rights are usually designed for citizens of wealthy and powerful countries rather than entire mankind itself. One may claim that since the European Court of Human Rights found Poland guilty of violating a torture ban, human rights eventually won. However, it must be taken into account that Guantanamo Bay still operates. There are still one hundred unlawfully captured detainees, some of them even without being charged and/or the possibility to contact a lawyer thus waiting several years to have a trial. At the same time, we should be very honest about the nationality and ethnicity of these detainees. Military commissions - American bodies having jurisdiction over captured detainees -were undoubtedly designed for non-US nationals. Delving deeper, regardless of their citizenship, undoubtedly all of them came from the Arabic world. As Mustafa Tagma suggested the racist background of American politics, it is hard to imagine a flag-waving suburban 'soccer mom' in the United States being thrown into a prison camp ${ }^{26}$. Moreover, in my opinion, any ruling and damages awarded to the tortured in a Polish 'black site' cannot undo the fact that people from certain countries are more likely to be subject of tortures.

Yet, it is quite clear that in general the only real rights are given to citizens by their states ${ }^{27}$. I argue that Guantanamo Bay, in turn, shows that in some cases, real rights are only given to the citizens of 'proper' ethnicities by 'proper' states. Unfortunately, human rights are not given to people on account of their participation in the human race, but are closely connected to citizenship and ethnic background. This paradox of human rights has also found expression in Žižek's phrase: "paradoxically, I am deprived of human rights at the very moment at which I am reduced to a human being 'in general'", 28 .

The gap between the term universal human rights and its significance does not rely on the warped understanding of the term 'human'. The other lie contains the word 'universal'. As Chantal Mouffe put it, as long as human rights are considered as something neutral and natural, they will always cause cultural conflicts ${ }^{29}$. This necessity of rejecting the universalness of human rights rests upon the subsequent beliefs.

Firstly, it should be considered that in every society something else could play the role of human rights. As Douzinas jokingly paraphrased Nietzsche: "if God, the source of natural law, is dead, he has been replaced

\footnotetext{
${ }^{25}$ Douzinas (n 3) 99.

${ }^{26}$ Halit Mustafa Tagma, 'Homo Sacer vs. Homo Soccer Mom: Reading Agamben and Foucault in the War on Terror' (2009) 34 Alternatives 407, 421.

27 ibid 10 .

28 Žižek, 'Against human rights' (n 24) 127.

${ }^{29}$ Mouffe (n 13) 143.
} 
by international law" ${ }^{\prime 30}$. In liberal democracy, religion and natural laws are replaced with a secular idea of human rights meanwhile, in some parts of the world, religion still plays the main role as a source of natural law.

The second thing is that a variety of natural rights sources implies the variety of its content. Anti mask-laws throughout Europe are explained in different ways but, as Žižek noticed, they are usually used against Muslims and rest upon the assumption that women have the right to enjoy themselves and have their own body at their own disposal ${ }^{31}$. The dignity of women finds expression in the right to be a sexual object of male interest. On the contrary, for Islam, the control of female sexuality is legitimized as the defense of women's dignity against being reduced to objects of male exploitation. Consequently, when the French or British prohibit Muslim girls from wearing a burka in school, one can claim that they are thus enabled to dispose of their bodies as they wish. However, one can also argue that the true point for critics of Muslim "fundamentalism" was that there were women who did not participate in the game of making their bodies available for sexual seduction $^{32}$. It might be said that, in general, complications with the universalness of human rights starts whenever human rights touch values in a material sense. Some human rights have a solely formal character (e.g. the right to a fair trial) therefore can usually be easily reconciled with other cultures. In contrast, when we assume that it is the right of every human to feel, behave and express any sexual orientation and gender of their own choice, again the non-universal dimension of human rights comes to the fore. For this reason, it is not a surprise that homosexuals, oppressed in some Muslim countries for being considered as sinners, are welcomed in the Western world as political refugees.

The last lie is the legal dimension of human rights. From a legal perspective, a right is a legal entitlement to effectively demand something. A right is a right, as long as it at least has the potential ability to cause legal effect. The point is that human rights are not applicable in circumstances of inhuman treatment. Every time that governors of liberal democracies send the concept of human rights abroad, they are already admitting that the receivercountry is unlawful. This refers to Lacan's formula of communication in which the sender gets his own message back from the receiver ${ }^{33}$. The content of the return message is obvious. The receiver-country is unlawful and human rights in these circumstances are incapable of being changed. That finds expression in the words of Jacques Ranciere who said that

"if those who suffer inhuman repression are unable to enact the human rights that are their last recourse, then somebody else has to inherit their rights in order to enact them in their place. This is what is called the "right to humanitarian interference" - a right that some nations assume to the supposed benefit of victimized populations. Then the 'right to humanitarian interference' might be described as a sort of

\footnotetext{
${ }^{30}$ Douzinas (n 3) 24.

${ }^{31}$ Žižek, 'Against human rights' (n 24) 119.

32 ibid.

33 ibid 128.
} 
'return to sender': the disused rights that had been sent to the rightless are sent back to the senders" 34 .

The aforementioned reflection concerns sending human rights abroad, in the sense of sending them from the West to the East, usually in the form of military intervention under the guise of human rights values. How effective are human rights in their homeland of Europe? When I analyzed who the bearer of human rights is, I had already signaled that some of the biggest, recent violations of human rights happened in European countries such as Poland and Romania. Here, as analyzing the entire data and effectiveness of the European Court of Human Rights, it is beyond the frame of this paper. I would just like to point out that European countries such as Italy, Greece, Romania, Poland, Hungary and Bulgaria have still been admonished by the Council of Europe because of being identified as having difficulties with the implementation of the Courts' judgments ${ }^{35}$. Seeing as European countries even violate human rights, it shows how vague and fragile this concept is in itself.

\section{Ideological and Postpolitcal Dimension of Human RIGHTS}

To conclude, I take the view that human rights prove that our times are, on one hand, highly ideological and on the other post-political. In this way, intensifies one another. The final hegemony of ideology starts there, where something stops being a subject of political discussion. However, considering human rights as something non-political does not imply they are not a tool for politicians. On the contrary, human rights are the best tool that any political system has ever had to expanse and consolidate its legitimacy without the risk of being accused of imperialist intentions.

The post-political dimension of human rights rests upon the fact that human rights as reality, in Huxley's world, are considered as something natural, neutral and unquestionable. Paradoxically, when human rights stop being a part of political discussion, they become the most useful political tool. As Slovene, legal theorist Renata Salecl put in:

"the discourse of universal human rights thus presents a fantasy scenario in which society and the individual are perceived as whole, as non-split. In this fantasy, society is understood as something that can be rationally organized, as the community that can become nonconflict if only it respect human rights" 36 .

As Douzinas noticed, the rhetoric of human rights have triumphed because they can be adopted by the left and the right, the north and the south, the state and the pulpit, and the minister and the rebel. This is a characteristic that makes them the only ideology in town, the ideology after the end of ideologies, the ideology which is believed to be preferred or the facade of

\footnotetext{
34 Jacques Rancière, 'Who is the Subject of the Rights of Man?' (2004) 103 (2-3) South Atlantic Quarterly 307-9.

${ }^{35}$ Committee on Legal Affairs and Human Rights, Implementation of Judgments of the European Court of Human Rights: 8th reports, 7.

${ }^{36}$ Renata Salecl, The Spoils of Freedom (London, Routledge 1994) 127.
} 
various ideological "isms ${ }^{37}$. Saying "human rights" implies associations with liberalism, capitalism and individualism. Considering Althusser's phrase that ideology always reveals in material practices, it should no longer surprise us that the twentieth-century development of universal human rights is consistent with the empirical observation that our age has witnessed their greatest violations ${ }^{38}$. The phrase that can encapsulate this dissertation is Douzinas's phrase that "human rights have only paradoxes to offer"39.

\section{References}

Douzinas C., Human Rights and empire: the political philosophy of cosmopolitanism (Taylor \& Francis e-Library 2007).

Fukuyama F., The End of History and the Last Man (Free Press 1992).

Huxley A., Brave New World (first published in 1932 by Chatto \& Windus) $<$ https://archive.org/download/ost-englishbrave new world aldous huxley/Brave New_World Aldous_Huxley.pdf $>$ accessed 4 July 2014.

Mouffe Ch., Polityczność (tr Joanna Erbel, Wydawnictwo Krytyki Politycznej 2008).

Mustafa Tagma H., 'Homo Sacer vs. Homo Soccer Mom: Reading Agamben and Foucault in the War on Terror' (2009) 34 Alternatives.

Orwell G., Nineteen Eighty-Four (first published in 1949 by Secker and Warburg) <http://www.planetebook.com/ebooks/1984.pdf > accessed 4 August 2014.

Rancière J., 'Who is the Subject of the Rights of Man?' (2004) 103 (2-3) South Atlantic Quarterly.

Salecl R., The Spoils of Freedom (London, Routledge 1994).

Scott E., 'Orwell, Huxley and the Emerging Totalitarianism' (May 2013) $<$ http://www.newenglishreview.org/custpage.cfm/frm/138161/sec id/13816 $1>$ accessed 4 July 2014

Žižek S., 'Ideology, the Party' (1 December 2011) $<\underline{\text { https://blogs.commons.georgetown.edu/engl-246- }}$ fall2011/2011/12/01/zizek-ideology-the-party/> accessed 4 August 2014.

Žižek S., 'Against human rights' (2005) 34 New Left Review 115, 130.

Žižek S., Wzniosty obiekt ideologii (trs Joanna Bator and Paweł Dybel, Wydawnictwo Uniwersytetu Wrocławskiego 2001).

\footnotetext{
${ }^{37}$ Douzinas (n 3) 33 .

${ }^{38}$ ibid 55.

39 ibid 100.
} 